Jurnal Indonesia Sosial Teknologi: p-ISSN: 2723 - 6609

e-ISSN : 2745-5254

Vol. 2, No. 3 Maret 2021

\title{
PENGARUH PERGERAKAN MAKROEKONOMI TERHADAP PEMBIAYAAN KONSTRUKSI PERBANKAN SYARIAH
}

\author{
Ahmad Sonjaya \\ Fakultas Ekonomi dan Bisnis UHAMKA, Jakarta Selatan, Indonesia \\ Email: madson_27@yahoo.co.id
}

\section{Abstract}

This study aims to see the impact of macroeconomic shocks on the financing of the Islamic banking construction sector by using a vector error correction model using monthly data from January 2010 to December 2018. The results show that the financing of the construction sector is slower to achieve stability. In the short term, none of them has a significant effect. Meanwhile, in the long term the variables of inflation, stock index, and crisis have a significant effect. Islamic banking financing on average reaches stability when it enters the fifteenth period. Interest rates begin to stabilize when entering the fifteenth period. The exchange rate stabilized when it entered the fourteenth period. Inflation started to stabilize when it entered the sixteenth period. The stock index began to stabilize when it entered the fifteenth period and the crisis began to stabilize when it entered the sixteenth period. In general, the one that has the greatest contribution in shaping diversity is the variable of Islamic banking financing, then inflation, stock index, crisis exchange rate and the smallest interest rate.

Keyword: financing; construction sector; islamic banking; VECM

\begin{abstract}
Abstrak
Penelitian ini bertujuan untuk melihat dampak dari guncangan makroekonomi terhadap pembiayaan sektor konstruksi perbankan syariah dengan menggunakan vector error correction model menggunakan data bulanan dari januari 2010 sampai dengan desember 2018. Hasil menunjukkan pembiayaan sektor kontruksi lebih lambat mencapai kestabilan. Pada jangka pendek tidak satu pun yang memiliki pengaruh signifikan. Sedangkan pada jangka panjang variabel inflasi, indeks saham, dan krisis memiliki pengaruh signifikan. Pembiayaan perbankan syariah rata-rata mencapai kestabilan ketika memasuki periode kelima belas. Suku bunga mulai stabil ketika memasuki periode kelima belas. Nilai tukar mulai stabil ketika memasuki periode keempat belas. Inflasi mulai stabil ketika memasuki periode keenam belas. Indeks saham mulai stabil ketika memasuki periode kelima belas dan krisis mulai stabil ketika memasuki periode keenam belas. Secara umum yang memiliki kontribusi paling besar dalam membentuk keragaman adalah variabel pembiayaan perbankan syariah, kemudian inflasi, indeks saham, nilai tukar krisis dan yang paling kecil suku bunga.
\end{abstract}

Kata kunci: pembiayaan; sektor konstruksi; perbankan syariah; VECM Pendahuluan 
Perbankan dalam menjalankan fungsinya sebagai lembaga intermediasi memiliki peranan yang sangat penting dalam menunjang pertumbuhan ekonomi suatu negara. Penghimpunan dana dari masyarakat kemudian menyalurkannya ke berbagai sektor ekonomi akan mampu mendorong bergeraknya seluruh sektor perekonomian (Minetti \& Peng, 2018; Önder \& Özy1ldırım, 2019). Melalui kebijakan ini, perbankan memiliki peranan penting dalam pemerataan pendapatan masyarakat, terutama bagi kalangan masyarakat yang memiliki sumber daya terbatas sehingga dapat memanfaatkan fasilitas kredit perbankan untuk membiayai berbagai macam kegiatan produksinya. Dengan demikian, melalui mekanisme sistem perbankan dan kebijakan kredit yang tepat, perbankan dapat menjalankan fungsinya untuk membantu pemerintah dalam pemerataan pendapatan masyarakat.

Kebijakan penyaluran pembiayaan/kredit perbankan sangat erat kaitannya dengan kondisi makroekonomi nasional (Rashid et al., 2020). Kondisi makroekonomi yang sehat akan mendorong kestabilan perekonomian nasional sehingga memicu perbankan untuk menyalurkan pinjaman pada masyarakat (Binici \& Hutchison, 2018). Kondisi makroekonomi dilihat melalui perkembangan beberapa variabel, seperti tingkat suku bunga (BI rate), nilai tukar rupiah, laju inflasi, Produk Domestik Bruto (PDB) (Bodie et al., 2008).

BI rate sebagai suku bunga acuan akan mempengaruhi suku bunga pinjaman dan simpanan yang ditetapkan perbankan, volatilitas nilai tukar rupiah menyebabkan ketidakstabilan perbankan dan dunia usaha, laju inflasi diperlukan oleh sebuah negara dalam batas yang wajar untuk menunjang pertumbuhan ekonomi negara dan pertumbuhan PDB akan didorong oleh serangkaian aktivitas kegiatan perekonomian dimana pada akhirnya akan menentukan permintaan kredit sektor perbankan (Aluko \& Ajayi, 2018; Ellington, 2018; Gershon et al., 2019; Ratti \& Vespignani, 2016). Pemerintah telah mengupayakan berbagai kebijakan terkait dengan stabilitas makroekonomi agar tercipta lingkungan ekonomi yang kondusif dalam berusaha dan berinvestasi. Kebijakan tersebut juga bertujuan mengembalikan fungsi intermediasi bank dalam penyaluran kredit kepada sektor ekonomi.

Perkembangan dunia perbankan tentunya akan menghadapi tantangan yang harus direspon secara tepat. Salah satu tantangan yang ada adalah adanya perubahan kondisi makroekonomi tersebut. Pengaruh makroekonomi penting dan pengaruhnya ada pada tingkat industri (Mora, 2015). Hasil ini juga mengungkapkan bagaimana guncangan ekonomi ditransmisikan ke penurunan industri, menyediakan kerangka kerja untuk risiko agregat dalam risiko pemulihan dan pengujian ekonomi makro (Aysun, 2016; Hossain, 2016). Transmisi guncangan makroekonomi ke ekonomi riil sebagian besar beroperasi melalui pinjaman bank besar dan neraca peminjam (Aysun, 2016). Selanjutnya, negara-negara dengan tingkat transparansi fiskal yang lebih tinggi cenderung memiliki tingkat inflasi dan volatilitas inflasi yang lebih rendah yang pada akhirnya mempengaruhi kredit perbankan pada negara-negara berkembang (Montes \& da Cunha Lima, 2018). 
Kebijakan fiskal sangat efektif dalam mengelola pertumbuhan kredit, volatilitas pertumbuhan kredit, dan mengurangi inflasi harga konsumen di Turki (Chadwick, 2018). Selain itu, pengaruh ini lebih menonjol ketika kebijakan fiskal disesuaikan dengan kebijakan moneter. Pengaruh faktor makroekonomi berupa inflasi, BI Rate dan Kurs terhadap non performing financing (NPF) (Hernawati \& Puspasari, 2018). Dengan menggunakan metode data panel, hasil penelitian menunjukkan inflasi tidak signifikan terhadap non performing financing (NPF), sedangkan BI Rate dan Nilai Tukar memiliki pengaruh signifikan terhadap non performing financing.

Sektor konstruksi merupakan sektor penting dalam mendukung proyek pembangunan di Indonesia. Pengembangan sektor konstruksi memerlukan peran sektor perbankan untuk membantu akses permodalan melalui pemberian pembiayaan dan kredit. Termasuk pembiayaan syariah yang cukup dibutuhkan oleh sektor konstruksi. Pembiayaan model syariah banyak dibutuhkan sektor kontruksi mengingat keunggulan produk pembiayaan perbankan syariah karena menggunakan sistem bagi hasil.

Pro dan kontra berdasarkan penelitian terdahulu menimbulkan pertanyaan, apakah perbankan di Indonesia juga merespon demikian atau bahkan menunjukkan hasil yang berbeda dengan penelitian sebelumnya. Oleh karena itu, kebaruan penelitian ini secara khusus akan mengkaji bagaimana respon yang terjadi pada perbankan dan bagaimana pihak perbankan seharusnya menghadapi kondisi ini terutama pembiayaan yang dilakukan perbankan syariah pada sektor konstruksi.

Penelitian ini bertujuan untuk menganalisis pengaruh makroekonomi terhadap pembiayaan sektor konstruksi pada perbankan syariah, menganalisis respon pembiayaan sektor konstruksi dalam menghadapi guncangan perubahan kondisi makroekonomi; dan menganalisis pergerakan makroekonomi mempengaruhi keragaman pembiayaan sektor konstruksi. Penelitian ini dapat memberikan manfaat diantaranya pertama, mengatahui faktor apa saja yang mempengaruhi pembiayaan sektor kontruksi pada jangka pendek dan jangka panjang. Kedua, penelitian ini diharapkan mampu menambah wawasan dan menjadi sarana pembelajaran pembiayaan sektor konstruksi. Ketiga, penelitian ini diharapkan mampu menjadi bahan pertimbangan dalam pengambilan keputusan yang berkaitan dengan pembiayaan sektor kontruksi. Keempat, penelitian ini diharapkan dapat menjadi bahan pertimbangan dalam menentukan pembiayaan sektor kontruksi.

\section{Metode Penelitian}

\section{A. Jenis dan Sumber Data}

Data yang digunakan pada penelitian ini menggunakan data primer dan data sekunder. Data primer digunakan untuk mengkonfirmasi hasil dari pengolahan data dengan wawancara para ahli, sedangkan data sekunder menggunakan data dalam bentuk bulanan yang diperoleh dari Otoritas Jasa Keuangan (OJK), pacific exchange rate service, Bank Indonesia (BI) dan Badan Pusat Statistik (BPS). Penelitian ini terdiri dari Bank Umum Syariah (BUS) dan Unit Usaha Syariah (UUS). Data kuantitatif yang digunakan merupakan data pada perbankan syariah, data nilai tukar yang merefleksikan nilai tukar mata uang Rupiah per Dollar Amerika Serikat, data inflasi yang 
merefleksikan perubahan tingkat harga dan BI Rate yang merefleksikan tingkat suku bunga acuan dan GDP merefkelsikan pertumbuhan ekonomi. Data yang digunakan dalam penelitian ini bersifat time series dengan periode bulan Januari 2010 sampai dengan bulan Desember 2018.

Tabel 1 Variabel penelitian

\begin{tabular}{|c|c|c|c|c|}
\hline Jenis Data & Simbol & Keterangan & Satuan & Sumber \\
\hline $\begin{array}{l}\text { Total Pembiayaan } \\
\text { Perbankan }\end{array}$ & $\mathrm{KON}$ & $\begin{array}{l}\text { Jumlah Pembiayaan } \\
\text { yang dilakukan } \\
\text { perbankan }\end{array}$ & $\begin{array}{l}\text { Milyar } \\
\text { Rupiah }\end{array}$ & $\begin{array}{l}\text { Otoritas Jasa } \\
\text { Keuangan }\end{array}$ \\
\hline Suku Bunga & BIRATE & $\begin{array}{l}\text { Acuan Suku Bunga } \\
\text { yang ditetapkan } \\
\text { Bank Indonesia }\end{array}$ & Persen & $\begin{array}{l}\text { Bank } \\
\text { Indonesia }\end{array}$ \\
\hline Nilai Tukar & EXRATE & $\begin{array}{lr}\text { Kurs } & \text { Rupiah } \\
\text { terhadap Dollar } & \text { Amerika Serikat }\end{array}$ & $\mathrm{Rp} / \mathrm{US} \$$ & $\begin{array}{l}\text { pacific } \\
\text { exchange } \\
\text { rate service }\end{array}$ \\
\hline Inflasi & CPI & $\begin{array}{lr}\text { Proxy } & \text { untuk } \\
\text { mengukur } & \text { tingkat } \\
\text { inflasi } & \end{array}$ & Persen & $\begin{array}{l}\text { Bank } \\
\text { Indonesia }\end{array}$ \\
\hline $\begin{array}{l}\text { Pertumbuhan } \\
\text { Ekonomi }\end{array}$ & GDP & $\begin{array}{l}\text { Pertumbuhan } \\
\text { Ekonomi }\end{array}$ & Persen & $\begin{array}{l}\text { Badan Pusat } \\
\text { Statistik }\end{array}$ \\
\hline
\end{tabular}

\section{B. Metode Pengolahan dan Analisis Data}

Seluruh data menggunakan data riil yang ditransformasikan ke dalam bentuk logaritma natural (LN), kecuali variabel yang sudah dalam satuan persen. Perangkat lunak yang digunakan pada penelitian ini adalah Microsoft Excel 2007 untuk mengelompokkan data dan pengolahan data dilakukan dengan menggunakan bantuan program Eviews 6. Penelitian ini menggunakan pendekatan metode analisis Vector Autoregressive (VAR) yang bertujuan untuk menjawab permasalahan penelitian.

Proses pengolahan data, jika ditemukan data yang digunakan tidak stasioner pada tingkat level, maka harus didiferensiasikan pada turunan pertama (first differencing) sehingga hasil tersebut memiliki hubungan jangka panjang (kointegrasi) dan model VAR akan dikombinasikan dengan model koreksi kesalahan menjadi Vector Error Correction Model (VECM) (Firdaus, 2006). Pada analisis VAR dan VECM ada beberapa tahap yang perlu dilakukan, yaitu uji stationeritas data, uji stabilitas, lag optimal, uji kointegrasi, penentuan model VECM, analisis Impulse Response Function (IRF) dan Variance Decomposition (VD).

\section{Metode Vector Autoregression (VAR)}

Jika sebelumnya univariate autoregression merupakan sebuah persamaan tunggal dengan model linier variabel tunggal, dimana nilai sekarang dari masing-masing 
variabel dijelaskan oleh nilai lag-nya sendiri, maka VAR merupakan sebuah $n$ persamaan dengan $\mathrm{n}$ variabel dengan masing-masing variabel dijelaskan oleh lag-nya sendiri, serta nilai saat ini dan masa lampaunya (Stock \& Watson, 2001). Dengan demikian dalam konteks ekonometrika modern VAR termasuk ke dalam multivariate time series analysis (Firdaus, 2006).

VAR menyediakan cara yang sistematis untuk menangkap perubahan yang dinamis dalam multiple time series, serta memiliki pendekatan yang kredibel dan mudah untuk dipahami bagi pendeskripsian data, peramalan, struktur inferensial serta analisis kebijakan (Stock \& Watson, 2001). Adapun analisa yang disediakan oleh VAR bagi deskripsi data, peramalan, inferensi struktural, dan analisis kebijakan dilakukan melalui empat macam penggunaannya, yaitu Forecasting, Impulse Respon Function (IRF), Forecast Error Decomposition (FEVD), dan Granger Caulality Test (Arsana, 2005). Forecasting merupakan ekstrapolasi nilai saat ini dan masa depan seluruh variabel dengan memanfaatkan seluruh informasi masa lalu variabel. Impulse Response Function (IRF) bermanfaat untuk melacak respon saat ini dan masa depan setiap variabel akibat perubahan atau shock suatu variabel tertentu. Forecast Error Variance Decomposition (FEVD) merupakan prediksi kontribusi persentase varians setiap variabel terhadap perubahan suatu variabel tertentu. Sedangkan Granger Causality Test bertujuan untuk mengetahui hubungan sebab-akibat antar variabel. Adapun persamaan umum VAR adalah sebagai berikut (Enders, 2004): $\mathrm{y}_{\mathrm{t}}=\mathrm{A}_{0}+\mathrm{A}_{1} \mathrm{y}_{\mathrm{t}-1}+\mathrm{A}_{2} \mathrm{y}_{\mathrm{t}-2}+\ldots+\mathrm{A}_{\mathrm{p}} \mathrm{y}_{\mathrm{t}-\mathrm{p}}+\mathrm{e}_{\mathrm{t}}$

di mana:

$\mathrm{y}_{\mathrm{t}} \quad=$ Vektor berukuran (n.1) yang berisikan $\mathrm{n}$ variabel dalam sebuah model VAR

$\mathrm{A}_{0} \quad=$ Vektor intersep berukuran (n.1)

$\mathrm{A}_{\mathrm{i}} \quad=$ Matriks koefisien/parameter berukuran (n.n) untuk setiap $\mathrm{i}=1,2 . ., \mathrm{p}$

$\mathrm{e}_{\mathrm{t}} \quad=$ Vektor error berukuran (n.1)

Spesifikasi model VAR meliputi pemilihan variabel yang sesuai dengan teori ekonomi yang relevan dan sesuai dengan pemilihan lag optimal yang digunakan dalam model (Firdaus, 2006). Dalam menentukan lag optimal yang digunakan dapat memanfaatkan kriterian informasi, seperti Akaike Information Criterion (AIC), Schwarz Information Criterion (SIC) dan Hannan Quinn Criterion (HQ) (Nachrowi \& Usman, 2006).

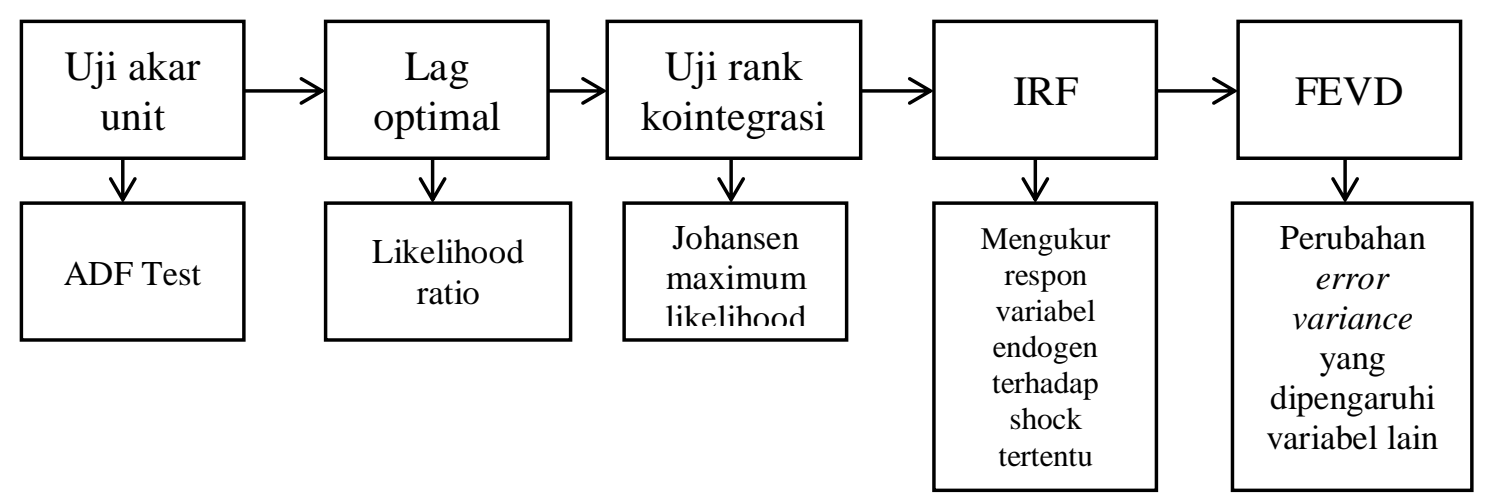




\section{Gambar 2. Alur tahapan pada analisis VECM}

\section{Metode Vector Error Correction Model (VECM)}

Vector Error Correction Model (VECM) merupakan bentuk VAR yang terestriksi (Enders, 2004). Restriksi tambahan ini harus diberikan karena keberadaan bentuk data yang tidak stasioner pada level, tetapi terkointegrasi. VECM kemudian memanfaatkan informasi restriksi kointegrasi tersebut ke dalam spesifikasinya. Karena itu, VECM sering disebut sebagai desain VAR bagi series non stasioner yang memiliki hubungan kointegrasi. Jika telah dilakukan pengujian kointegrasi pada model yang digunakan, maka dianjurkan untuk memasukkan persamaan kointegrasi ke dalam model yang digunakan. Pada data time series umumnya memiliki tingkat stasioneritas pada perbedaan pertama (first difference). Sehingga dalam VECM terdapat speed of adjustment dari jangka pendek ke jangka panjang. Untuk mengantisipasi hilangnya informasi jangka panjang, maka dalam penelitian ini akan digunakan model VECM apabila ternyata terdapat data yang digunakan tidak stasioner pada level. Secara umum model VECM sebagai berikut:

$$
\Delta \mathrm{y}_{\mathrm{t}}=\mu_{0 \mathrm{x}}+\mu_{1 \mathrm{x}} \mathrm{t}+\prod_{\mathrm{x}} \mathrm{y}_{\mathrm{t}-1}+\sum_{i=1}^{k-1} \Gamma_{i x} \Delta \mathrm{y}_{t-i}+\varepsilon_{\mathrm{t}}
$$

di mana :

$\mathrm{y}_{\mathrm{t}} \quad=$ vektor yang berisi variabel yang dianalisis dalam penelitian

$\mu_{0 \mathrm{x}} \quad=$ vektor intersept

$\mu_{1 \mathrm{x}} \quad=$ vektor koefisien regresi

$\mathrm{t} \quad=$ periode waktu

$\prod_{\mathrm{x}}=\alpha_{\mathrm{x}} \beta$ dimana $\mathrm{b}$ mengandung persamaan kointegrasi jangka panjang

$\mathrm{y}_{\mathrm{t}-1} \quad=$ variabel in-level

$\Gamma_{i x} \quad=$ matriks koefisien regresi

$\mathrm{k}-1=$ ordo VECM dari VAR

$\varepsilon_{\mathrm{t}} \quad=$ error term

\section{Hasil dan Pembahasan}

\section{A. Statistika Deskriptif}

Data yang digunakan dalam penelitian ini, dirangkum secara komprehensif pada Tabel 4. Data belum terdistribusi secara normal, kecuali data dari BRTE yang dibuktikan dari nilai probability Jarque-Bera lebih besar dari 5 persen sedangkan distribusi simetris yang ditunjukkan variabel tersebut secara umum memiliki ekor panjang di sisi kiri (negetif skewness). Secara umum, dilihat dari kurtosis yang muncul ternyata ukuran ketinggian dari distribusi data adalah datar (platykurtic). Standar deviasi yang digunakan pada penelitian ini menggambarkan ukuran penyebaran data yang mendekati rata-ratanya. 
Tabel 2 Hasil Statistik Deskriptif

\begin{tabular}{lcccccc}
\hline & KOST & BRTE & EXCH & INFL & IHSG & KRIS \\
\hline Mean & -8.581868 & 2.708034 & -9.305938 & 0.437516 & -8.225605 & 0.298137 \\
\hline Median & -8.588397 & 2.733368 & -9.262382 & 0.330000 & -8.360806 & 0.000000 \\
\hline Maximum & -6.822197 & 3.158251 & -9.050500 & 3.290000 & -7.124109 & 1.000000 \\
\hline Minimum & -10.21024 & 2.079442 & -9.628498 & -0.450000 & -8.795678 & 0.000000 \\
\hline Std. Dev. & 1.164628 & 0.226870 & 0.184698 & 0.525710 & 0.454479 & 0.458867 \\
\hline Skewness & 0.021450 & -0.103083 & -0.176329 & 1.863288 & 0.811436 & 0.882579 \\
\hline Kurtosis & 1.422080 & 3.020610 & 1.356762 & 9.413731 & 2.583546 & 1.778945 \\
\hline Jarque-Bera & 16.71496 & 0.287981 & 18.94834 & 369.1147 & 18.83127 & 30.90365 \\
\hline Sum & -1381.681 & 435.9935 & -1498.256 & 70.44000 & -1324.322 & 48.00000 \\
\hline Observations & 161 & 161 & 161 & 161 & 161 & 161 \\
\hline
\end{tabular}

\section{B. Pengujian Stasioneritas Data}

Pemeriksaan kestasioneran data time series pada setiap variabel mengunakan pengujian Augmented Dickey Fuller (ADF). Jika nilai dari t-ADF lebih besar dari pada nilai MacKinnon critical value maka data tersebut telah bersifat stasioner pada taraf nyata 5 persen (taraf nyata yang ditentukan). Selain itu, dapat juga dilihat dari nilai probabilitasnya. Jika nilai probabilitasnya kurang dari 5 persen maka data tersebut sudah bersifat stasioner.

Berdasarkan hasil uji yang telah dilakukan, maka dapat disimpulkan bahwa data pembiayaan sektor konstruksi (KOST), suku bunga (BRTE), nilai tukar rupiah (EXCH), inflasi (INFL), indeks saham (IHSG) dan krisis (KRIS) belum stasioner pada level, kecuali INFL. Data yang tidak stationer pada level maka perlu dilanjutkan pada first difference. Ketika data menggunakan first difference, data telah menjadi stasioner termasuk juga INFL. Hal tersebut dibuktikan dengan nilai prob* kurang dari 5 persen. Penggunaan data first difference tidak direkomendasikan sebab akan menghilangkan informasi jangka panjang. Oleh sebab itu, untuk menganalisis informasi jangka panjang akan digunakan data level sehingga model VAR akan dikombinasikan dengan model koreksi kesalahan (error correction model) atau VECM.

Tabel 3 Hasil Pengujian Stasioneritas Data

\begin{tabular}{lcccr}
\hline \multirow{2}{*}{ Variable } & \multicolumn{2}{c}{ Level } & \multicolumn{2}{c}{ First Difference } \\
\cline { 2 - 5 } & t-statistic & Prob. ${ }^{*}$ & t-statistic & Prob. ${ }^{*}$ \\
\hline KOST & -0.403874 & 0.9045 & -13.06065 & 0.0000 \\
\hline BRTE & -2.337490 & 0.1616 & -5.008893 & 0.0000 \\
\hline EXCH & -0.818048 & 0.8110 & -9.869277 & 0.0000 \\
\hline INFL & -9.493424 & 0.0000 & -10.54257 & 0.0000 \\
\hline IHSG & -1.993041 & 0.2897 & -9.524941 & 0.0000 \\
\hline KRIS & -2.201505 & 0.2067 & -12.52996 & 0.0000 \\
\hline
\end{tabular}




\section{Pengujian Lag Optimal}

Pengujian panjang lag optimal dapat dilakukan dengan cara memanfaatkan beberapa informasi yang diperoleh, yaitu dengan cara menggunakan kriteria Likehood Ratio (LR), Final Prediction Error (FPE), Akaike Information Criterion (AIC), Schwarz Information Criterion (SC) dan Hannan-Quinn Criterion (HQ). Jika kriteria informasi hanya merujuk pada sebuah kandidat selang, maka kandidat tersebutlah yang dipilih sebagai panjang selang optimal. Jumlah lag yang optimal dalam penelitian ini didasarkan pada nilai Schwarz Information Criterion (SC) yang terkecil atau minimum. Penetapan lag optimal model yang dibangun dapat dilihat pada Tabel 6.

Tabel 4 Hasil Pengujian Lag Optimal

\begin{tabular}{ccccccc}
\hline Lag & LogL & LR & FPE & AIC & SC & HQ \\
\hline 0 & -28.25697 & NA & $6.30 \mathrm{e}-08$ & 0.447804 & 0.566644 & 0.496079 \\
\hline 1 & 1133.849 & 2217.875 & $2.55 \mathrm{e}-14$ & -14.27254 & - & -13.93461 \\
& & & & & $13.44065^{*}$ & \\
\hline 2 & 1195.792 & 113.3604 & $1.82 \mathrm{e}-14 *$ & - & -13.06674 & - \\
& & & & $14.61166^{*}$ & & $13.98409^{*}$ \\
\hline 3 & 1221.913 & 45.75378 & $2.08 \mathrm{e}-14$ & -14.48252 & -12.22455 & -13.56530 \\
\hline 4 & 1254.734 & 54.91672 & $2.19 \mathrm{e}-14$ & -14.44097 & -11.46995 & -13.23409 \\
& & $*$ & & & & \\
\hline 5 & 1277.400 & 36.14616 & $2.65 \mathrm{e}-14$ & -14.26666 & -10.58260 & -12.77014 \\
\hline 6 & 1302.247 & 37.67655 & $3.15 \mathrm{e}-14$ & -14.12087 & -9.723767 & -12.33470 \\
\hline 7 & 1333.366 & 44.74667 & $3.47 \mathrm{e}-14$ & -14.05707 & -8.946922 & -11.98124 \\
\hline 8 & 1369.953 & 49.73908 & $3.61 \mathrm{e}-14$ & -14.06474 & -8.241550 & -11.69927 \\
\hline
\end{tabular}

* indicates lag order selected by the criterion

LR: sequential modified LR test statistic (each test at $5 \%$ level)

FPE: Final prediction error

AIC: Akaike information criterion

SC: Schwarz information criterion

HQ: Hannan-Quinn information criterion

Berdasarkan kriteria yang digunakan pada penelitian ini (SC terkecil), terlihat bahwa lag yang terpilih adalah lag 1 . Oleh sebab itu, persamaan VAR dari model yang dibangun berdasarkan lag optimal telah terbentuk adalah sebagai berikut (urutan variabel berdasarkan correlation matrix) :

$$
\Delta \mathrm{x}_{\mathrm{t}}=\pi_{0}+\pi \mathrm{x}_{\mathrm{t}-1}+\pi_{1} \Delta \mathrm{x}_{\mathrm{t}-1}+\varepsilon_{\mathrm{t}}
$$

di mana :

$\mathrm{x}_{\mathrm{t}}=$ Vektor yang berisi variabel yang dianalisis dalam penelitian (KOST)

$\pi_{0}=$ Vektor intersep berukuran (n.1)

$\pi=$ Matriks dengan elemen $\pi_{\mathrm{jk}}$, di mana $\pi_{\mathrm{jk}} \neq 0$; (KOST, BRTE, EXCH, INFL, IHSG dan KRIS)

$\pi_{1}=$ Matriks koefisien berukuran (n.n) dengan elemen $\pi_{\mathrm{jk}}(\mathrm{i})$; (KOST, BRTE, EXCH, INFL, IHSG dan KRIS)

$\varepsilon_{\mathrm{t}}=$ Vektor error berukuran (n.1) dengan elemen $\varepsilon_{\mathrm{it}}$ 


\section{Pengujian Stabilitas Data}

Hasil estimasi sistem persamaan VAR yang telah terbentuk harus diuji stabilitasnya melalui VAR stability condition check yang berupa roots of characteristic polynomial terhadap seluruh variabel yang digunakan dikalikan jumlah lag dari masingmasing VAR. Jika modulus dari seluruh roots of characteristic polynomial kurang dari 1 maka sistem persamaan VAR dikategorikan stabil. Setelah sistem persamaan VAR stabil maka dapat dilakukan estimasi terhadap VECM. Model penyaluran pembiayaan sektor konstruksi terdiri dari 6 variabel dengan lag sebanyak satu, maka jumlah root yang diuji sebanyak $6\left(6^{*} 1=6\right)$. Berdasarkan hasil uji stabilitas VAR, dapat disimpulkan bahwa sistem VAR yang digunakan bersifat stabil. Hal tersebut dapat dibuktikan dari 6 root yang diuji pada model pembiayaan sektor konstruksi memiliki modulus dari seluruh roots of characteristic polynomial dengan kisaran $0.353259-0.996847$ atau kurang dari 1.

\section{Tabel 5 Hasil Pengujian Stabilitas Data}

\begin{tabular}{ll}
\hline \multicolumn{1}{c}{ Root } & Modulus \\
\hline 0.996847 & 0.996847 \\
\hline 0.954241 & 0.954241 \\
\hline 0.949123 & 0.949123 \\
\hline $0.850104-0.118686 \mathrm{i}$ & 0.858349 \\
\hline $0.850104+0.118686 \mathrm{i}$ & 0.858349 \\
\hline 0.353259 & 0.353259 \\
\hline
\end{tabular}

No root lies outside the unit circle.

VAR satisfies the stability condition.

\section{E. Pengujian Kointegrasi}

Pengujian kointegrasi dilakukan dalam rangka untuk melihat hubungan jangka panjang setiap variabel yang digunakan dalam penelitian ini meskipun jika dilihat secara individu tidak stasioner, namun secara kombinasi linier menjadi stasioner. Dikarenakan data yang diperoleh tidak semua stasioner pada level maka akan dilakukan estimasi dengan menggunakan Vector Error Correction Model (VECM), sehingga perlu dilakukan pengujian kointegrasi terlebih dahulu.

Kointegrasi digunakan untuk memperoleh persamaan jangka panjang yang stabil. Pada analisis ini, uji kointegrasi digunakan untuk melihat apakah metode VECM dapat digunakan atau tidak. Jika terdapat lebih dari nol rank kointegrasi, maka metode VECM dapat digunakan dalam analisis. Uji kointegrasi yang dipakai berdasarkan Johansen Cointegration Test berdasarkan Trace Statistic untuk mengetahui jumlah persamaan yang terkointegrasi didalam sistem.

Tabel 6 Hasil uji kointegrasi

\begin{tabular}{ccccc}
\hline Hypothesized & Eigenvalue & $\begin{array}{c}\text { Trace } \\
\text { Statistic }\end{array}$ & $\begin{array}{c}\mathbf{0 . 0 5} \\
\text { Critical Value }\end{array}$ & Prob.** \\
\cline { 1 - 4 } No. of CE $(\mathrm{s})$ & 0.464380 & 200.9533 & 117.7082 & 0.0000 \\
\hline None ${ }^{*}$ & 0
\end{tabular}




\begin{tabular}{ccccc}
\hline At most $1 *$ & 0.239859 & 101.6847 & 88.80380 & 0.0043 \\
\hline At most 2 & 0.179671 & 58.07874 & 63.87610 & 0.1396 \\
\hline At most 3 & 0.086255 & 26.58877 & 42.91525 & 0.7046 \\
\hline At most 4 & 0.053202 & 12.24638 & 25.87211 & 0.7947 \\
\hline At most 5 & 0.022104 & 3.553915 & 12.51798 & 0.8052 \\
\hline
\end{tabular}

Trace test indicates 2 cointegrating eqn(s) at the 0.05 level

* denotes rejection of the hypothesis at the 0.05 level

**MacKinnon-Haug-Michelis (1999) p-values

Bila nilai trace statistic lebih besar dari critical value, maka pada tingkat tersebut kita dapat menerima hipotesis $\mathrm{H}_{1}$ yang menyatakan jumlah rank kointegrasi. Berdasarkan Tabel 7, model yang dibangun pada penelitian ini memiliki dua rank terkointegrasi pada taraf nyata 5 persen. Hal ini berarti bahwa terdapat minimal dua persamaan kointegrasi yang mampu menerangkan keseluruhan model yang dibangun. Adapun penggunaan kointegrasi untuk intepretasi pada hasil kajian yang akan dijelaskan selanjutnya dengan menggunakan kointegrasi yang pertama. Setelah rank kointegrasi diketahui, selanjutnya informasi jumlah rank kointegrasi ini akan digunakan sebagai error correction model yang akan dimasukkan kedalam VECM.

\section{F. Hasil Pengujian VECM}

Model pembiayaan perbankan syariah pada sektor konstruksi memiliki hubungan pada jangka panjang karena memiliki kointegrasi pada variabel yang diujikan. Dengan menggunakan Vector Error Correction (VECM) dapat melihat keseimbangan jangka panjang dengan tetap membiarkan keberadaan dinamika jangka pendek dari persamaan yang terkointegrasi karena data tidak stasioner namun memiliki kointegrasi menggunakan restriksi tambahan. Model terbaik yang dipilih berdasarkan dari kriteria goodness of fit. Intepretasi dari VECM adalah dengan melihat koefisiennya. Namun, koefisien yang dilihat di sini adalah koefisien setelah menyesuaikan error coorection atau penyesuaian dari jangka pendek ke jangka panjang.

Penelitian ini menggunakan taraf nyara 5 persen sebagai nilai kritisnya. Tabel 8 merupakan hasil estimasi VECM pada model pembiayaan perbankan syariah sektor kontruksi yang memperlihatkan hubungan variabel pada jangka pendek maupun jangka panjang. Adapun aturannya variabel yang memiliki pengaruh signifikan digambarkan dari hasil mutlak t-statistik lebih besar dari hasil t-tabel pada taraf nyata 5 persen sebesar 1,9749 .

Mekanisme penyesuaian dari jangka pendek ke jangka panjang yang ditunjukkan dengan kointegrasi kesalahan menunjukkan hasil yang signifikan. Kondisi tersebut menunjukkan bahwa terdapat penyesuaian dari jangka pendek ke jangka panjang atau dengan kata lain pembiayaan perbankan syariah pada sektor kontruksi lebih lambat mencapai kestabilan. Namun, semua variabel yang diteliti pada jangka pendek tidak satu pun yang memiliki pengaruh signifikan. 
Sedangkan pada jangka panjang variabel INFL, IHSG dan KRIS memiliki pengaruh signifikan. Kenaikan INFL dan IHSG dalam jangka panjang kenaikan sebesar satu persen akan meningkatkan pembiayaan sektor konstruksi masing-masing sebesar 5,94 persen dan 6,43 persen sedangkan KRIS dalam jangka panjang kenaikan sebesar satu persen akan menurunkan pembiayaan sektor konstruksi sebesar 1,56 persen.

Kondisi ini menggambarkan kenaikan INFL dan IHSG menyebabkan peningkatan pembiayaan perbankan syariah pada sektor konstruksi. Namun adanya krisis menyebabkan penurunan pembiayaan perbankan syariah pada sektor konstruksi. Kondisi ini menggambarkan bahwa pertumbuhan ekonomi tentu akan diringi dengan kenaikan inflasi. Semakin tumbuh perekonomian suatu negara tentu akan menjadikan iklim investasi semakin baik sehingga sektor konstruksi membutuhkan dana tambahan untuk melakukan ekspansi bisnisnya.

Tabel 7 Hasil Pengujian VECM

\begin{tabular}{lcc}
\hline \multirow{2}{*}{ Variabel } & Koefisien & $\mid$ |t-statistik \\
\cline { 2 - 3 } & \multicolumn{2}{c}{ Jangka Pendek } \\
\hline CointEq1 & 0.004633 & $2.03738^{*}$ \\
\hline $\mathrm{D}($ KOST(-1)) & -0.063206 & -0.77658 \\
\hline $\mathrm{D}(\mathrm{BRTE}(-1))$ & 0.078121 & 0.45568 \\
\hline $\mathrm{D}(\mathrm{EXCH}(-1))$ & -0.071447 & -0.28012 \\
\hline $\mathrm{D}(\mathrm{INFL}(-1))$ & -0.002119 & -0.18513 \\
\hline $\mathrm{D}(\mathrm{IHSG}(-1))$ & 0.067700 & 0.64668 \\
\hline $\mathrm{D}($ KRIS(-1)) & 0.001505 & 0.04561 \\
\hline & \multicolumn{2}{c}{ Jangka Panjang } \\
\hline BRTE(-1) & 3.885173 & 1.78450 \\
\hline EXCH(-1) & -1.465089 & -0.33651 \\
\hline INFL(-1) & 5.949033 & $11.4087^{*}$ \\
\hline IHSG(-1) & 6.431547 & $3.43771^{*}$ \\
\hline KRIS(-1) & -1.565633 & $-2.20769^{*}$ \\
\hline
\end{tabular}

Penguatan kondisi pasar modal berpengaruh secara signifikan bagi peningkatan penyaluran pembiayaan ke sektor konstruksi sebesar 6,43 persen. Krisis global yang menerjang berpengaruh terhadap pembiayaan perbankan syariah pada sektor konstruksi. Hal tersebut dapat dilihat dari laju pertumbuhan pembiayaan yang menurun sebesar 1,56 persen. Para pelaku usaha sektor kontruksi yang berorientasi ekspor akan merasakan dampak yang cukup signifikan dalam operasional usahanya sehingga menurunnya penyaluran pembiayaan ke sektor konstruksi.

Nilai tukar mata uang yang semakin menguat menandakan bahwa kondisi perekonomian jauh lebih baik dibandingkan dengan sebelumnya, namun dalam penelitian ini pergerakan mata uang tidak berpengaruh signifikan pada penyaluran pembiayaan ke sektor konstruksi. Begitu pula dengan kenaikan suku bunga acuan 
dimana nilainya tidak berpengaruh signifikan pada penyaluran pembiayaan ke sektor konstruksi. Hal ini lebih disebabkan karena debitur yang menjadi nasabah perbankan syariah tidak berpatokan pada suku bunga melainkan tingkat bagi hasil antara nasabah dan pihak perbankan.

\section{G. Impulse Response Function (IRF)}

IRF berguna untuk menunjukkan bagaimana respon suatu variabel dari sebuah guncangan variabel itu sendiri maupun variabel lainnya. Penelitian ini menggunakan jangka waktu 30 bulan ke depan untuk mengeahui respon dari pembiayaan yang dilakukan perbankan syariah pada sektor konstruksi.

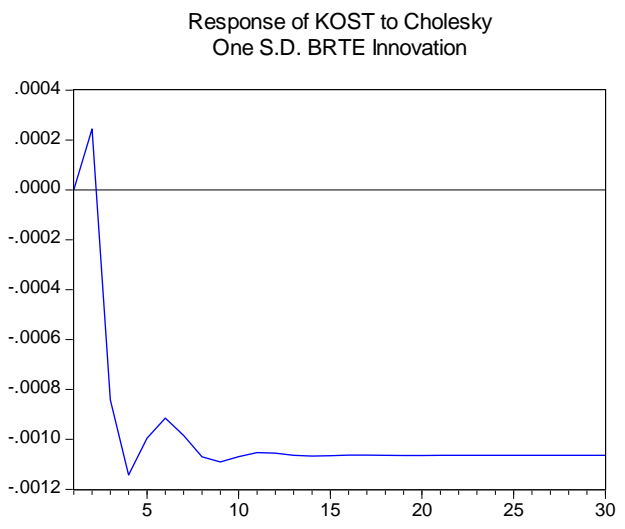

\section{Gambar 3. Respon Pembiayaan Sektor Kontruksi terhadap Guncangan Suku Bunga}

Guncangan suku bunga (Gambar 3) sebesar 1 standar deviasi pada bulan pertama belum terlihat adanya perubahan pembiayaan sektor kontruksi. Hal ini disebabkan karena pembiayaan sektor kontruksi membutuhkan waktu untuk merespon. Memasuki bulan kedua mulai terlihat respon positif dari pembiayaan sektor kontruksi walaupun masih kecil sebesar 0,000244 persen dan langsung turun direspon negatif pada bulan ketiga mencapai - 0.000841 terus turun sampai bulan keempat kemudian naik dan mulai stabil memasuki bulan ketiga belas sampai dengan bulan ketiga puluh.

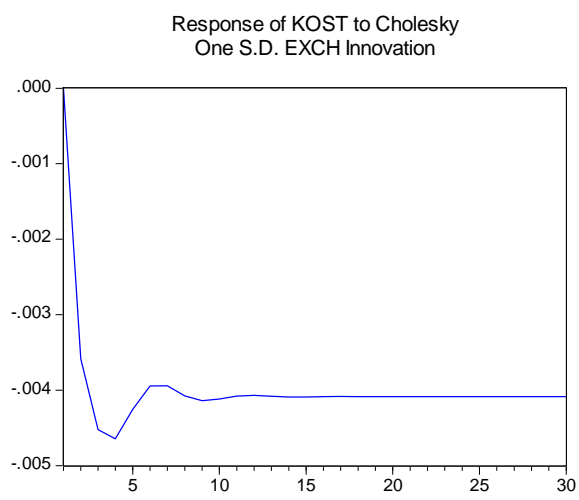




\section{Gambar 4. Respon Pembiayaan Sektor Kontruksi terhadap Guncangan Nilai Tukar}

Guncangan nilai tukar (Gambar 4) sebesar 1 standar deviasi pada bulan pertama belum terlihat adanya perubahan pembiayaan sektor kontruksi. Hal ini disebabkan karena pembiayaan sektor kontruksi membutuhkan waktu untuk merespon. Memasuki bulan kedua mulai terlihat respon negatif dari pembiayaan sektor kontruksi walaupun masih kecil sebesar - 0.003584 persen kemudian turun hingga bulan keempat sebesar 0.004644 lalu mulai beranjak naik hingga mulai stabil ketika memasuki bulan kelima belas sampai dengan bulan ketiga puluh.

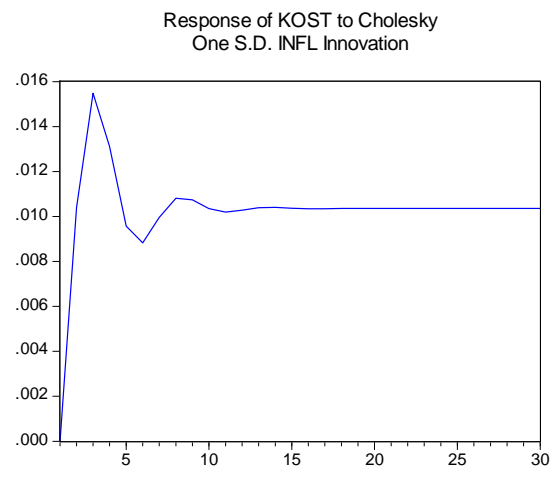

\section{Gambar 5. Respon Pembiayaan Sektor Kontruksi terhadap Guncangan Inflasi}

Guncangan inflasi (Gambar 5) sebesar 1 standar deviasi pada bulan pertama belum terlihat adanya perubahan pembiayaan sektor konstruksi. Hal ini disebabkan karena pembiayaan sektor kontruksi membutuhkan waktu untuk merespon. Memasuki bulan kedua mulai terlihat respon negatif dari pembiayaan sektor kontruksi walaupun masih kecil sebesar -0.003584 persen kemudian turun hingga bulan keempat sebesar 0.004644 lalu mulai beranjak naik hingga mulai stabil ketika memasuki bulan kelima belas sampai dengan bulan ketiga puluh.

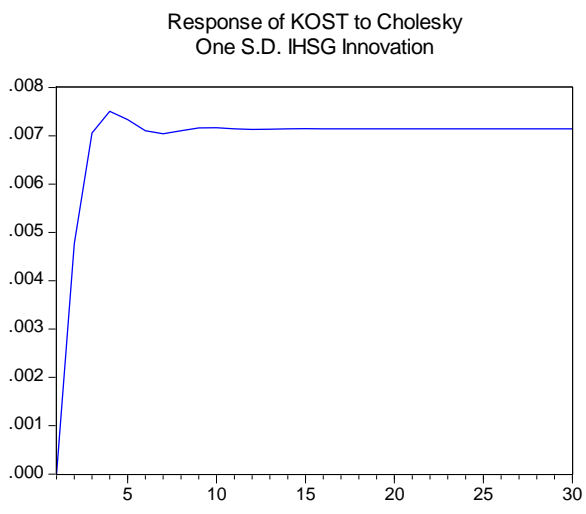




\section{Gambar 6. Respon Pembiayaan Sektor Kontruksi terhadap Guncangan Saham}

Guncangan saham (Gambar 6) sebesar 1 standar deviasi pada bulan pertama belum terlihat adanya perubahan pembiayaan sektor kontruksi. Hal ini disebabkan karena pembiayaan sektor kontruksi membutuhkan waktu untuk merespon. Memasuki bulan kedua mulai terlihat respon positif dari pembiayaan sektor kontruksi walaupun masih kecil sebesar 0.004765 persen kemudian naik hingga bulan keempat sebesar 0.007508 lalu mulai beranjak turun hingga mulai stabil ketika memasuki bulan kelima belas sampai dengan bulan ketiga puluh.

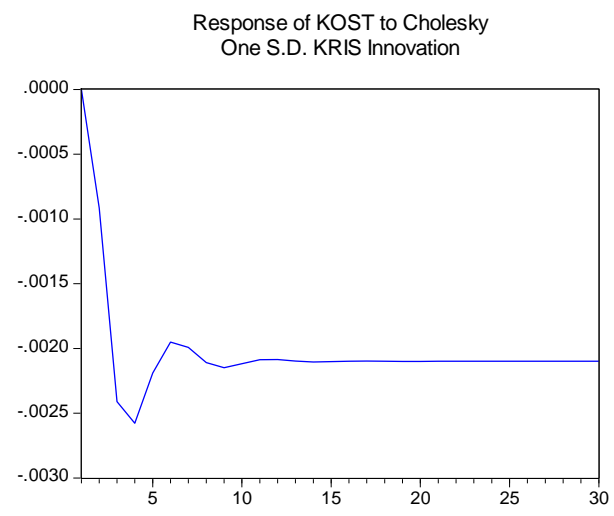

\section{Gambar 7. Respon Pembiayaan Sektor Kontruksi terhadap Guncangan Krisis}

Guncangan saham (Gambar 7) sebesar 1 standar deviasi pada bulan pertama belum terlihat adanya perubahan pembiayaan sektor kontruksi. Hal ini disebabkan karena pembiayaan sektor kontruksi membutuhkan waktu untuk merespon. Memasuki bulan kedua mulai terlihat respon negatif dari pembiayaan sektor kontruksi walaupun masih kecil sebesar -0.000916 persen kemudian terus turun hingga bulan keempat sebesar - 0.002578 lalu mulai beranjak niak hingga mulai stabil ketika memasuki bulan kelima belas sampai dengan bulan ketiga puluh.

\section{H. Forecast Error Decomposition Variance (FEVD)}

Pergerakan setiap variabel akibat terjadinya suatu guncangan dapat dilakukan dengan mengkaji peranan setiap guncangan dalam menjelaskan pergerakan variabelvariabel yang diteliti melalui analisis dekomposisi variance. Analisis jangka panjang pada penelitian ini menggunakan model VECM melalui simulasi dekomposisi variance. Hasil variance decomposition pada model perbankan syariah di Indonesia memperlihatkan bahwa dalam interval peramalan variance pembiayaan sektor kontruksi (KONS) sangat disebabkan oleh inovasi KONS itu sendiri. 
Simulasi yang disajikan pada Gambar 6 menunjukkan bahwa pada periode pertama guncangan variabel dipengaruhi oleh guncangan pembiayaan syariah itu sendiri sebesar 100 persen, sementara variabel lainnya tidak berpengaruh. Kontribusi guncangan variabel lain mulai dirasakan pada periode kedua pengamatan meskipun persentase yang mempengaruhi sangat kecil. Hal ini dikarenakan memerlukan waktu untuk mempengaruhi aspek lainnya.

Guncangan inflasi memberikan kontribusi terbesar dibandingkan dengan variabel lainnya diperiode ini sebesar 1.31651 persen dan terus meningkat hingga akhir pengamatan. Indeks saham berada pada posisi kedua pada periode ini dan sampai dengan akhir pengamatan dengan kontribusi sebesar 0.276564 persen. Kemudian disusul dengan nilai tukar dengan kontribusi sebesar 0.156451 persen, guncangan krisis sebesar 0.01021 persen dan terakhir suku bunga sebesar 0.000727 persen. Pengaruh guncangan KONS terhadap dirinya sendiri semakin menurun seiring dengan bertambahnya waktu dan variabel lainnya memberikan kontribusi yang relatif mengalami peningkatan.

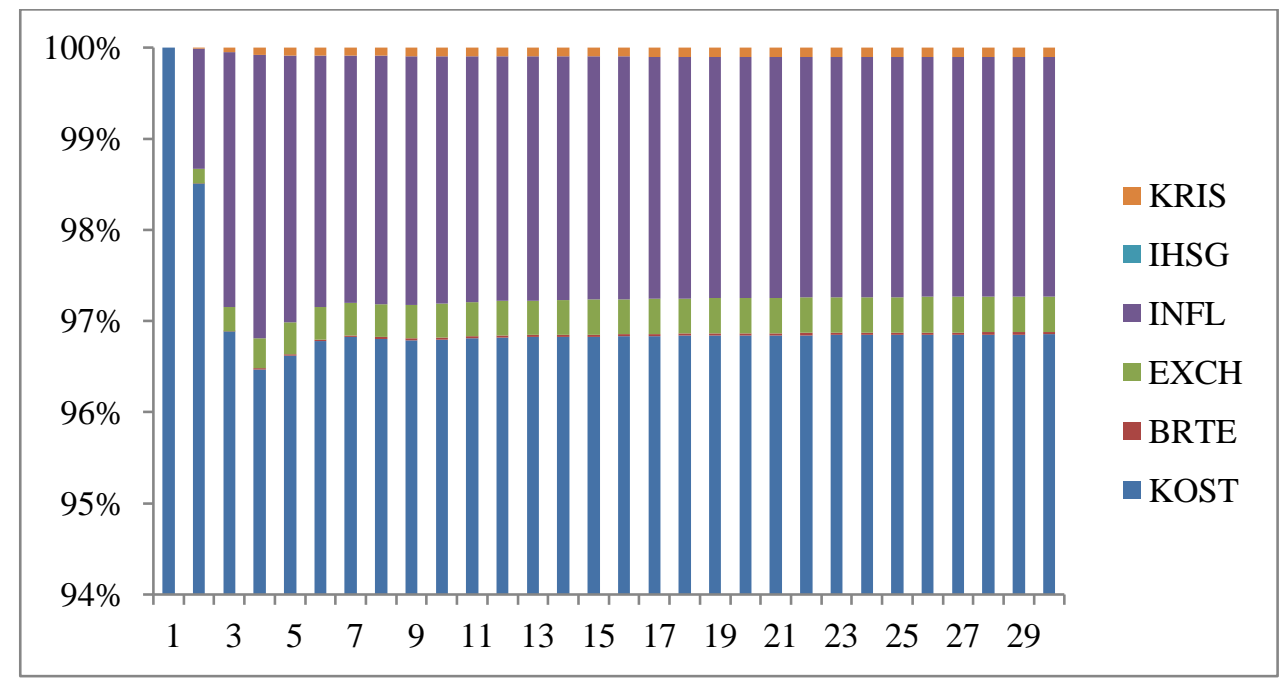

Gambar 8. Variance Decomposition model perbankan syariah

\section{Kesimpulan}

Hasil pengujian menggunakan vector error correction model terdapat penyesuaian dari jangka pendek ke jangka panjang atau dengan kata lain pembiayaan perbankan syariah pada sektor kontruksi lebih lambat mencapai kestabilan. Namun, semua variabel yang diteliti pada jangka pendek tidak satu pun yang memiliki pengaruh signifikan. Sedangkan pada jangka panjang variabel INFL, IHSG dan KRIS memiliki pengaruh signifikan. Hasil pengujian menggunakan impulse response function menunjukkan pembiayaan perbankan syariah rata-rata mencapai kestabilan ketika memasuki periode kelima belas. Suku bunga mulai stabil ketika memasuki periode kelima belas. Nilai tukar mulai stabil ketika memasuki periode keempat belas. Inflasi mulai stabil ketika memasuki periode keenam belas. Indeks saham mulai stabil ketika 
memasuki periode kelima belas dan krisis mulai stabil ketika memasuki periode keenam belas. Hasil pengujian menggunakan forecast error variance decomposition secara umum yang memiliki kontribusi paling besar dalam membentuk keragaman adalah variabel pembiayaan perbankan syariah, kemudian inflasi, indeks saham, nilai tukar krisis dan yang paling kecil suku bunga.

Dari hasil penelitian, sebaiknya perbankan syariah mewaspadai pergerakan inflasi, harga saham dan krisis yang memiliki pengaruh signifikan. Variabel tersebut perlu diawasi dengan seksama, karena pergerakannya akan berdampak pada kestabilan pembiayaan sektor kontruksi. Terlihat bahwa pergerakan variabel tersebut membuat pembiayaan sektor kontruksi mengalami kontraksi sampai periode kelima belas. Selain itu, variabel tersebut berkontribusi dalam mempengaruhi keragaman pembiayaan sektor kontruksi. Perbankan syariah perlu menyiapkan dana cadangan, dan membuat portofolio pembiayaan, agar dapat menyalurkan pembiyaan yang lebih efisien. 


\section{Bibliography}

Aluko, O., \& Ajayi, M. A. (2018). Determinants of Banking Sector Development: Evidence from Sub-Saharan African countries. Borsa Istanbul Review, 18(2), 122139. https://doi.org/10.1016/j.bir.2017.11.002

Arsana, I. (2005). Dasar-dasar Ekonometrika. Universitas Indonesia.

Aysun, U. (2016). Bank size and macroeconomic shock transmission: Does the credit channel operate through large or small banks? Journal of International Money and Finance, 65, 117-139. https://doi.org/10.1016/j.jimonfin.2016.04.001

Binici, M., \& Hutchison, M. (2018). Do Credit Rating Agencies Provide Valuable Information in Market Evaluation of Sovereign Default Risk? Journal of International Money and Finance, 85, 58-75. https://doi.org/10.1016/j.jimonfin.2018.04.001

Bodie, Z., Kane, A., \& Marcus, A. (2008). Essential Of Investments 7th Edition. The McGraw-Hill.

Chadwick, M. G. (2018). Effectiveness of monetary and macroprudential shocks on consumer credit growth and volatility in Turkey. Central Bank Review, 18(2), 6983. https://doi.org/10.1016/j.cbrev.2018.03.001

Ellington, M. (2018). Financial Market Illiquidity Shocks and Macroeconomic Dynamics: Evidence from the UK. Journal of Banking and Finance, 89, 225-236. https://doi.org/10.1016/j.jbankfin.2018.02.013

Enders, W. (2004). Applied Econometrics Time Series. John Wiley \& Sons Inc.

Firdaus, M. (2006). Analisis Deret Waktu Satu Ragam. IPB Press.

Gershon, O., Ezenwa, N. E., \& Osabohien, R. (2019). Implications of Oil Price Shocks on Net oil-importing African Countries. Heliyon, 5(8), 1-12. https://doi.org/10.1016/j.heliyon.2019.e02208

Hernawati, H., \& Puspasari, O. R. (2018). Pengaruh Faktor Makroekonomi terhadap Pembiayaan Bermasalah. Journal of Islamic Finance and Accounting, 1(1), 29-44. https://doi.org/10.22515/jifa.v1i1.1134

Hossain, A. A. (2016). Inflationary Shocks and Real Output Growth in Nine Muslimmajority Countries: Implications for Islamic Banking and Finance. Journal of Asian Economics, 45, 56-73. https://doi.org/10.1016/j.asieco.2016.06.004

Minetti, R., \& Peng, T. (2018). Credit policies, macroeconomic stability and welfare: The case of China. Journal of Comparative Economics, 46(1), 35-52. https://doi.org/10.1016/j.jce.2016.11.005 
Ahmad Sonjaya

Montes, G. C., \& da Cunha Lima, L. L. (2018). Effects of fiscal transparency on inflation and inflation expectations: Empirical evidence from developed and developing countries. Quarterly Review of Economics and Finance, 70, 26-37. https://doi.org/10.1016/j.qref.2018.06.002

Mora, N. (2015). Creditor recovery: The macroeconomic dependence of industry equilibrium. Journal of Financial Stability, 18, 172-186. https://doi.org/10.1016/j.jfs.2015.04.004

Nachrowi, N. D., \& Usman, H. (2006). Pendekatan Populer dan Praktis Ekonometrika untuk Analisis Ekonomi dan Keuangan. Lembaga Penerbit Fakultas Ekonomi Universitas Indonesia.

Önder, Z., \& Özyıldırım, S. (2019). Foreign banks and short-term macroeconomic fluctuations: Do financial development and regions matter? Economic Systems, 43(1), 63-76. https://doi.org/10.1016/j.ecosys.2018.08.007

Rashid, A., Hassan, M. K., \& Shah, M. A. R. (2020). On The Role of Islamic and Conventional Banks in the Monetary Policy Transmission in Malaysia: Do Size and Liquidity Matter? Research in International Business and Finance, 52, 1-33. https://doi.org/10.1016/j.ribaf.2019.101123

Ratti, R. A., \& Vespignani, J. L. (2016). Oil Prices and Global Factor Macroeconomic Variables. Energy Economics, 59, 198-212. https://doi.org/10.1016/j.eneco.2016.06.002

Stock, J. H., \& Watson, M. W. (2001). Vector Auto Regressions. Journal of Economic Perspectives, 15(4), 101-115. 